\begin{tabular}{|l|}
\hline Complications of embolism \\
- Postembolisation syndrome: \\
Malaise \\
Fever \\
Pain \\
Leucocytosis \\
- Specific to embolisation: \\
Tissue ischaemia \\
Tissue breakdown \\
Sepsis \\
Inadvertent embolisation of normal \\
tissue \\
- Related to angiography: \\
Renal failure \\
Vessel dissection \\
Reaction to contrast medium \\
Reaction to anaesthetic \\
\hline
\end{tabular}

treatment to some patients for whom none was possible previously.

Interventional radiology is developing fast. New techniques, equipment, and embolic agents are continually being introduced. It may soon be possible safely to embolise group 3 lesions percutaneously or from the venous side. In addition, work is progressing on instruments through which direct laser destruction of vascular endothelium will be possible.

Whatever new developments arise the key to safe and effective treatment of arteriovenous malformations is the closest possible cooperation between clinician and radiologist. In particular, surgical ligation of the main feeding arteries as an alternative to complete surgical excision must be avoided at all costs as this may preclude subsequent embolisation.

The lymphangioma was prepared by the audiovisual department, St Mary's Hospital, London, and the remaining illustrations were prepared by Westway Graphics, Hammersmith Hospital, London.

Professor D J Allison, FRCR, is professor of diagnostic radiology, and Dr Anne Kennedy, FRCR, is senior registrar in diagnostic radiology, at Hammersmith Hospital, London.

The ABC of Vascular Diseases has been edited by Mr John H N Wolfe, FRCS.

\title{
Health and the Environment
}
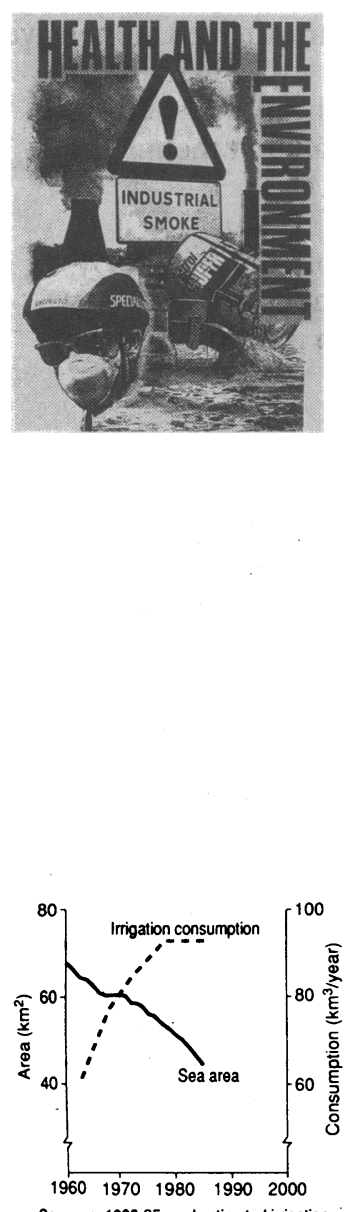

Sea 1960.85 and estimetedinition consumption, 1963-87, in Aral Sea basin ${ }^{3}$

British Medical Journal, London WC1H 9JR Alison Walker, MRCP, former editorial registrar

Correspondence to:

Department of Paediatrics, St Mary's Hospital, London W2 1NY.

BMf 1991;303:1194-7

\section{Population: more than a numbers game}

\section{Alison Walker}

On 11 July 1987 the world's population officially reached five billion - a landmark date. But the peak has not yet been reached. Numbers are still rising and estimates have again been revised upwards. The latest projections from the United Nations Population Fund now put the world's population at 10 billion by $2050 .^{1}$

But the earth cannot sustain an ever increasing rise in world population. Already the effect is taking its toll on the environment; global warming, ozone depletion, and acid rain have all been caused by man through industrial expansion; and overexploitation of land in the Third World has caused grasslands to deteriorate, soil erosion to increase, and land to be slowly converted to desert. In terms of human need, the long term effects of environmental change are still being debated, but a more urgent concern is now being raised. Environmental changes are already affecting agriculture and are threatening food production all over the world. Harvests are suffering, and estimates show the current food production is leaving one fifth of the world's current population without enough food.'

The cause is not simply maldistribution. After a record grain harvest in 1986, absolute grain production worldwide dropped by $5 \%$ in 1987 and by a further $5 \%$ in 1988, when the grain harvests of the United States, Canada, the Soviet Union, and China suffered from severe drought and crop failure. Meanwhile the world's population grew by $3.6 \%$ in 1987 and 1988. The United States' grain harvest was affected the most, falling by $27 \%$ in 1988 compared with the previous year. Over 100 nations depend on food imports from the United States, and only the large reserves have prevented a serious food crisis. Africa is more dependent that most, not only having the highest population growth anywhere in the world but also declining food production. Civil wars in Ethiopia, the Sudan, and elsewhere over the past two decades have resulted in widespread famines as local crops have been damaged and transport routes for food donations disrupted.

\section{Falling food production}

Despite estimates indicating a return of food production to 1986 levels there is still a need to replenish lost food reserves. A review of the world's food supply suggests that the world could be losing 14 million additional tons of grain output each year because of environmental damage to land and crops (table I).

TABLE I-Crude estimate of additional loss of world grain output each year as result of environmental degradation

\begin{tabular}{|c|c|c|}
\hline Form of degradation & $\begin{array}{r}\text { Grain o } \\
\text { (milli }\end{array}$ & $\begin{array}{l}\text { atput loss } \\
\text { n tons) }\end{array}$ \\
\hline \multicolumn{3}{|l|}{ Land degradation: } \\
\hline Soil erosion & & 9 \\
\hline Waterlogging and salting of irrigated land & & 1 \\
\hline $\begin{array}{l}\text { Loss of soil organic matter from burning cow dung } \\
\text { and crop residue }\end{array}$ & \} & \\
\hline Shortening of shifting cultivation cycle & \} & $2^{\star}$ \\
\hline Compaction of soil from heavy equipment & \} & \\
\hline \multicolumn{3}{|l|}{ Crop damage: } \\
\hline Air pollution & & 1 \\
\hline Flooding & \} & \\
\hline Acid rain & \} & $1^{\star}$ \\
\hline Increased ultraviolet radiation & \} & \\
\hline
\end{tabular}

$\star$ Because lack of data makes it difficult to quantify the crop losses from these three sources their effect is estimated collectively.

Soil erosion, for example, is estimated to be reducing the productivity of one third of the world's cropland. In India an estimated six billion tons of topsoil-the equivalent of $21000 \mathrm{~km}^{2}$ of arable land-is being lost every year. Land irrigation without adequate drainage is also affecting food production, causing waterlogging and salting as water evaporates and concentrates salts in the upper few layers of soil. Vast areas of the United States and Soviet Union have been made unproductive in this way. The Aral Sea region of the Soviet Union, for example, has been turned into an ecological disaster by the diversion of rivers to irrigate the surrounding farmland (fig). The sea is drying up, and the irrigated cropland has been turned into a salt desert. Dust, dried pesticides, and salt from the area have been carried thousands of miles away by winds and rain.

Each year some $3300 \mathrm{~km}^{3}$ of water are removed from the earth's rivers, streams, and undergound aquifers to water crops. Water is being drawn from aquifers faster 


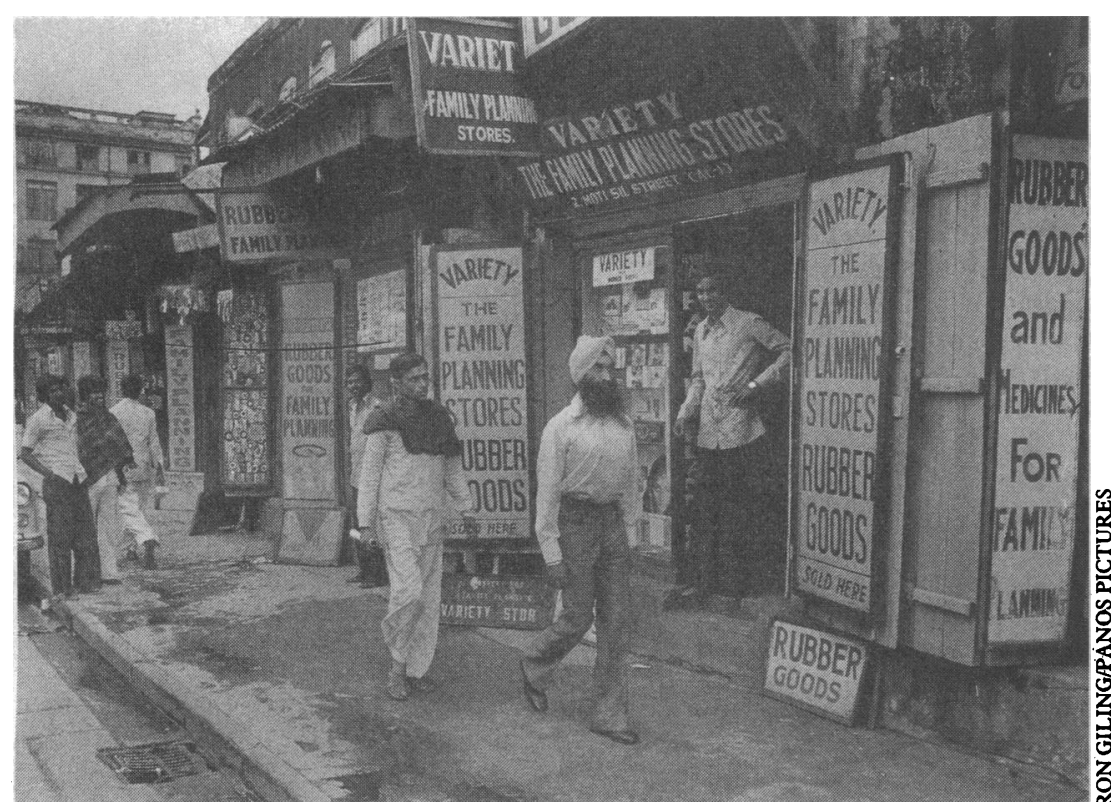

Demand for contraception around the world has never been higher

than it is being replaced, and in the United States more than four million hectares are watered by pumping in excess of replenishment. Deforestation is also taking its toll, increasing the run off of water from land and altering the pattern of recycling of rainfall on to cropland. Air pollution from cars and coal fired power stations is also damaging crops, ozone causing by far the most harm. And sensitive crops such as soya beans are being destroyed by the rise in ultraviolet radiation caused by depletion of the ozone layer in the upper stratosphere. $^{23}$

The green revolution has been responsible for the bigger world harvests of the past four or five decades as the result of advances in science and agriculture. But it cannot be guaranteed to continue. Farmers in the Third World may still be helped to improve food production, not only through biotechnology but by protecting soil and restoring the productivity of degraded land. But if the gap between food production and demand is to be narrowed, then the population question also needs to be tackled.

\section{Population side of the food equation}

Current indicators show a continuing fall in the rate of growth of the world's population, both in developed countries and in the Third World. ${ }^{4}$ This has been caused by a worldwide fall in fertility first noticed between 1960 and 1970 . The world growth rate reached an all time high in the late 1960 s at $2.04 \%$. Since then it has fallen, and in the mid-1980s was only $1 \cdot 67 \%$

A falling growth rate does not, however, mean that the world's population problems are over. Far from it. Population growth is exponential and will continue to rise even if birth rates fall, although at a slower rate. Projections from the United Nations suggest that population growth may continue until the twenty second century and may not level off until it reaches 11.6 billion. $^{1}$

The growth rates in industrialised and Third World countries are diverging (table II). By 2025 the population of the industrialised countries will have fallen from a third to less than a fifth of the world's population while the Third World will have increased its share of the population to more than $80 \%$. A greater fall in fertility rates in developed countries partly accounts for this change. Low fertility rates are responsible for the growth rates of only $1 \%$ a year or less now found in the United States, Australia, and New Zealand.' In Europe the fertility rate has declined from $2 \cdot 1$ births per woman in 1965 (the rate needed to maintain the size of its population) to only $1 \cdot 7$, causing Europe to slip from $15.6 \%$ of the world population in 1950 to $10 \cdot 2 \%$ in 1985 . Migration into Europe means that the population will not fall, but migrants from poor to rich countries pose an additional environmental threat, taking on the lifestyle of their adopted country, consuming resources, and causing environmental damage. But there is a positive side to this migration as the departure of people from the Third World reduces demand in their countries of origin.

The picture is quite different for the developing countries, where the total fertility rate, although falling, was still over four births per woman in the early 1980 s. At least $95 \%$ of the projected increase in growth of the world's population will take place in developing countries, which are growing at a rate of at least $2.5 \%$ per year adding some 65 million people a year to their populations. $^{5}$

Africa is experiencing the largest growth rate ever seen anywhere in the world. By the end of the century its population will have reached 900 million -250 million more than today-representing a growth rate of $3 \%$ per year. Asia still has more than half of the world's population, although its growth rate is much less than that of Africa. Population growth on this scale has forced previously self sufficient rural populations to over exploit their farm lands. An estimated $\mathbf{5 8 0}$ million people are living in absolute poverty on marginal or fragile land. One of the results has been mass migration from subsistence farming to the cities.

Explosive urban growth is now being seen in almost all parts of the developing world, particularly in places like Mexico City, Cairo, and São Paolo. More than 85 countries have city populations double those of 10 years ago, and by the end of the century the urban population of the developing world will be almost double that of the developed world. ${ }^{1}$ Inadequate sanitation, housing, food, and water all contribute to a desperate situation in which social and political troubles frequently ensue. But why has the fertility rate of the developed world fallen so much more than that of the Third World? Answering this question will provide some clues as to ways of controlling population growth.

\section{Controlling population growth}

Controlling the population growth in the Third World is, unfortunately, not that easy. While the developed world has managed to reduce both its birth and its death rates, the Third World is still experiencing falling death rates coupled with high (and in some places rising) birth rates (box). Social and political instability, falling per person incomes, declining agricultural productivity, and landlessness in the Third World all need to be tackled if its soaring population is to be reduced.

Not least of the hurdles to be overcome in the developing world is inadequate health care. Already hampered by widespread malnutrition, contaminated

TABLE II-Evolution of the world's population, by main region. ${ }^{4}$ Figures are numbers in millions (percentages)

\begin{tabular}{lcccc}
\hline & 1950 & 1985 & 2000 & 2025 \\
\hline World & 2516 & 4837 & 6122 & 8206 \\
Developed countries & $832(33 \cdot 1)$ & $1174(24 \cdot 3)$ & $1277(20 \cdot 9)$ & $1396(17 \cdot 0)$ \\
Developing countries & $1684(66 \cdot 9)$ & $3663(75 \cdot 7)$ & $4846(79 \cdot 2)$ & $6809(83 \cdot 0)$ \\
Africa & $224(8 \cdot 9)$ & $555(11 \cdot 5)$ & $872(14 \cdot 2)$ & $1617(19 \cdot 7)$ \\
Latin Amèrica & $165(6 \cdot 6)$ & $405(8 \cdot 4)$ & $546(8 \cdot 9)$ & $779(9 \cdot 5)$ \\
Asia & $1376(54 \cdot 7)$ & $2818(58 \cdot 3)$ & $3549(58 \cdot 0)$ & $4535(55 \cdot 3)$ \\
China & $555(22 \cdot 1)$ & $1060(21 \cdot 9)$ & $1256(20 \cdot 5)$ & $1475(18 \cdot 0)$ \\
India & $358(14 \cdot 2)$ & $759(15 \cdot 7)$ & $964(15 \cdot 8)$ & $1229(15 \cdot 0)$ \\
Europe & $392(15 \cdot 6)$ & $492(10 \cdot 2)$ & $512(8 \cdot 4)$ & $524(6 \cdot 4)$ \\
United States & $152(6 \cdot 0)$ & $238(4 \cdot 9)$ & $268(4 \cdot 4)$ & $312(3 \cdot 8)$ \\
Soviet Union & $180(7 \cdot 2)$ & $278(5 \cdot 7)$ & $315(5 \cdot 1)$ & $368(4 \cdot 5)$ \\
\end{tabular}


water supplies, and poor sanitaton, it is now further burdened by the speed with which the AIDS epidemic is taking hold, particularly in Africa. Projections from the United Nations predict that even in the worst scenario-if HIV seroprevalence reached $21 \%$ by the year 2000, implying an AIDS related death rate of 12 per 1000 population - the population of Africa will still be increasing at the turn of the century. ${ }^{1}$ But even they recognise that this estimate does not take into account the crippling effect that the epidemic will have on the already suffering health care system.

\section{Aid programmes}

Relief agencies, attempting to battle with the problems of the Third World, have come to recognise the need to integrate aid programmes. Population control through family planning, in particular, will not succeed unless other issues are also addressed. Unicef strongly emphasises the importance of combining family planning with primary health care. It sees family planning as one of four synergistic measures-the others being economic progress, improvements for women, and reduced child mortality - which act to reduce birth rates.

Infant mortality is particularly contentious. Maurice King, consultant public health physician in Leeds, questions the point of improving the health of infants in Third World countries when it is not matched by other efforts. "Such measures as oral rehydration should not be introduced on a public health scale," he writes, "since they increase the man-years of human misery, ultimately from starvation." Unicef, however, stresses the importance of reducing child death rates in order to achieve lower birth rates. Firstly, it says, an infant death ends the suppression of ovulation which is caused by breast feeding. Secondly, the death of a child can prompt couples to replace the loss by a new pregnancy, and, thirdly, when child death rates are high many parents anticipate loss of their children by having more than they actually want.

\section{Family planning}

Some countries have reduced fertility rates by successfully integrating family planning into the primary health care system. In Sri Lanka, for example, emphasis has been placed on women's development and maternal and child health alongside family planning. Female literacy rates are in excess of $80 \%$ and contraceptives are now used regularly by almost $70 \%$ of the population. ${ }^{1}$

Effective family planning is still used by only

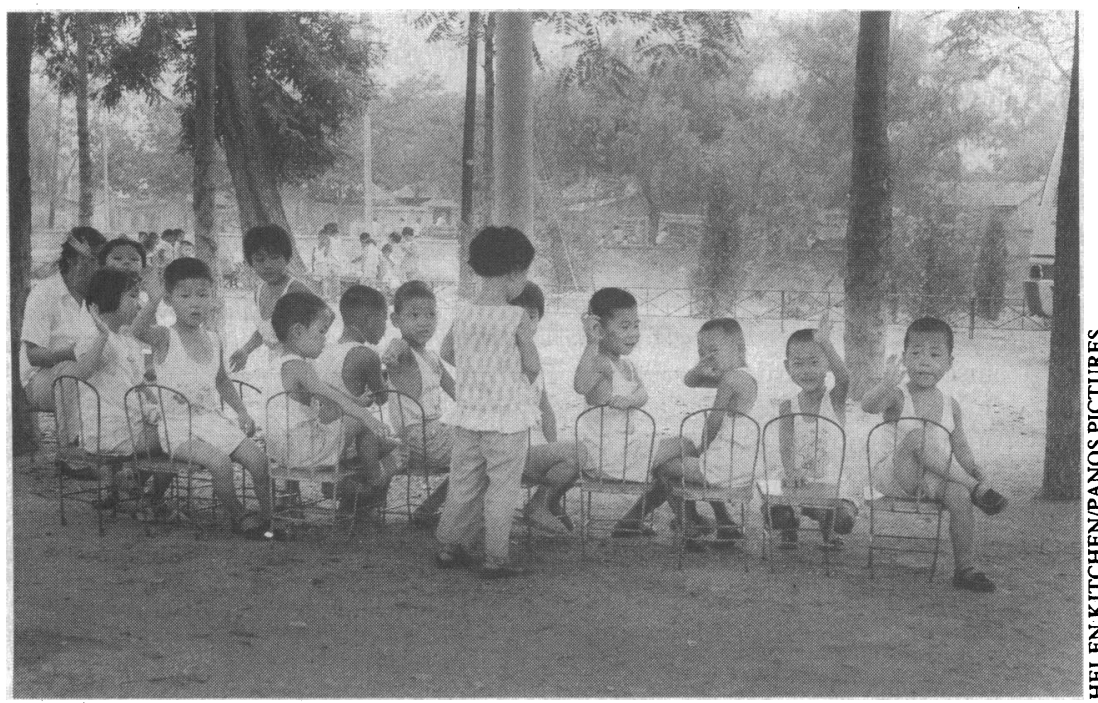

The world's population may be 10 billion by 2050

\section{The demographic trap}

In 1945 Notestein described a theoretical model of demographic transition to a stable equilibrium of low birth and death rates. The model gave three stages.

- Birth rates and death rates are high and the population grows slowly if at all

- Living and health conditions improve and death rates fall, but birth rates remain high and the population grows rapidly

- Economic and social gains combine to reduce birth rates, and, as in the first stage, birth rates and death rates are in equilibrium, but at a much lower level.

This picture was based on the experience in Europe, where transition to the third stage happened in the nineteenth century. Many Third World countries today, however, have fallen into a demographic trap unforeseen by Notestein, failing to complete the transition and reach the third stage. ${ }^{6}$ Unable to achieve the social and economic gains necessary to reduce births, they ultimately experience a rise in their death rates again. The population reaches an unsustainable state, with a high birth rate and death rate and increasing.pressure on its resources. Although there is little evidence for this "trap," the possibility of such processes is worth considering.

just over half of all married couples in developing countries.' Clearly use needs to increase, but getting the message across is difficult. Cultural beliefs that sterility is a curse need to be discussed with care, but other social, religious, and political barriers also need to be surmounted.

China managed to reduce its birth rate much faster than anyone would have thought possible. The successful reduction of the fertility rate from 4.74 at the beginning of the 1970 s to 2.36 just 10 years later had much to do with family planning being a "civic duty" under the Chinese constitution. ${ }^{4}$ Families who complied were rewarded with incentives-including better housing, better educational facilities, free child care, paid time off for abortions and sterilisations, and paid maternity leave. ${ }^{2}$ Although the programme was extremely successful, by the end of the 1970s the population had climbed to one billion. In 1979 the one child family was made the official "goal" for $50 \%$ of all couples and two children for the rest. With these additional measures the average family size had fallen to just $2 \cdot 1$ by the mid-1980s. But family planning in most developing countries does not have the political support given to it in China.

The exclusive support of family planning as part of primary health services can be hampered by ill equipped clinics staffed by underpaid government workers. ${ }^{9}$ Other channels for distributing contraceptives do exist and in many cases community based schemes through non-government organisations are more effective. In Nigeria, for example, the familiarity and accessibility of the markets make them a more successful means of distributing contraceptives-even though they are not free - than the local family planning association.'

Any investment in family planning is increasingly likely to succeed-figures show that demands for contraceptives around the world have never been so high. According to a survey carried out by the United Nations, a large proportion of married women in the Third World do not want any more children-the figures ranging from $12 \%$ in the Ivory Coast to $77 \%$ in the Republic of Korea. ${ }^{4}$

\section{Support from industrialised countries}

The United Nations Population Fund has set targets for slowing the growth of the world's population. Its 


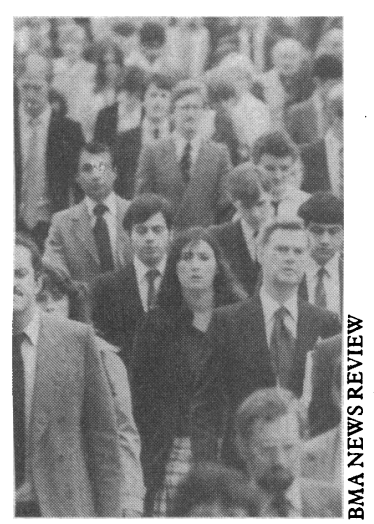

City populations have doubled over the past decade long term aim is to ensure that family planning services are available to all couples, but it has set a short term target of making them available to 567 million couples $-59 \%$ of all married women of reproductive age-by the year 2000. This will help ensure a fall in total fertility in developing countries from $3 \cdot 8$ to $3 \cdot 3$ children per woman.

To meet its target the population fund will require a doubling of its funding to $\$ 9 \mathrm{bn}$ annually by the year 2000 , half of which will have to come from the international community. Current support given by industrialised nations varies, but it is still pitifully low. ${ }^{10}$ In 1990 only $0.9 \%$ of the total development assistance budget provided by industrialised nations was spent on population or family programmes.

Financial aid is not the only way the developed world can help the Third World. One of the greatest contributions it can make is to ensure that the Third World learns from the industrialised world's mistakes. There seems little point in industrialised countries trying to. exricate themselves from the effects of the damage they have caused to the environment if the mistakes are simply going to be repeated by the Third World.

Two hundred years after Thomas Malthus, population growth remains a problem. Three interlinked issues - food, health, and family planning - are all central to the population issue, and the lack of them is felt most acutely in the Third World. Population control is an urgent problem which should not be neglected, nor confined to Third World debates. Everyone-especially doctors as part of their public health duty - should make population growth as much a public concern as global warming, acid rain, and other ecological issues." At the end of the day, however, it will be the political and economic motives of politicians which decide the fate of the world's population.

I thank Mr Timothy Dyson of the London School of Economics and Political Sciences for his help in compiling this article.

1 United Nations Population Fund. The state of world population 1991. New York: United Nations Population Fund, 1991.

Ehrlich PR, Ehrlich AH. The population explosion. New York: Simon and Schoster, 1990.

3 Worldwatch Institute. State of the world 1990. New York: N W Norton, 1990 4 United Nations Department of International Economic and Social Affairs. World population at the turn of the century. New York: United Nations, 1989. World Health Organisation. From Alma ata to the year 2000: reflections at the midpoint. Geneva: WHO, 1988.
morid

midpoint. Geneva: WHO, 1988.
Brown L. Analysing the demographic trap. In: The state of the world 1987. New Brown L. Analysing the demog
York: N W Norton, 1987.

7 Unicef. The state of the world's children 1991: Oxford: Oxford University Press, 1991

8 King M. Health is a sustainable state. Lancet 1990;336:664-7.

9 Nothing is unthinkable. Lancet 1990;336:659-61.

0 Potts $M$, Rosenfield $A$. The fifth freedom revisited. 1. background and existing programmes. Lancet 1990;336:1227-31.

11 Smith T. The population bomb has exploded already. BMf 1990;301:681-2.

\section{OBITUARY}

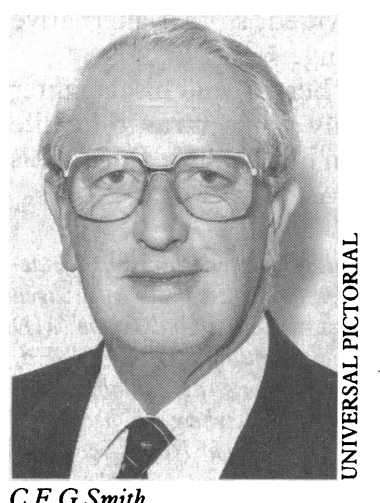

CE G Smith

\section{E G SMITH \\ $\mathrm{CB}, \mathrm{MD}, \mathrm{FRCP}, \mathrm{FRCPATH}$}

In 1964 Gordon Smith was persuaded to become director of the Microbiological Research Establishment at Porton Down, Wiltshire, and during his six years there he transformed it from an object of suspicion visited by protest marchers to an open and scientifically respected laboratory. There he first showed the striking ability to handle a mixture of science, administration, and politics in the teeth of adversity that marked his subsequent career.

In 1970 the London School of Hygiene and Tropical Medicine was looking for a strong dean and Gordon was the obvious choice. His ability to cope with difficult problems was further tested. Funding had become tight, the building was about to fall down, its inside was archaic, and the academic structure was outdated. Added to this were two major mishaps concerning smallpox. Gordon's financial prudence was fully stretched by funding crises, but he coped: nobody was made redundant. He was dean for 19 years, and the fact that the school still exists is his greatest monument.

Gordon saw the need for epidemiology to be developed as a discipline and a means to promote public health, and his energy overflowed to other organisations: he was concerned with the Wellcome Trust; conceived the idea of the Caribbean Epidemiological Centre; and was chairman of the board of the Public Health Laboratory Service and helped create the Communicable Disease Surveillance Centre. As

Obituaries of any doctors will be considered for publication. Obituaries must be submitted exclusively to the BMF and should be up to about 250 words long; they should be sent within six months, and preferably within three months, of death. "Self written" obituaries are welcome. Good quality, recent photographs are encouraged.
Geeping his loyalties to each separate. He confused issues with the people advocating them; one could strongly disagree with him on one issue, knowing that it would not affect any others under discussion. Though sometimes casually dogmatic, he had a deep sense of justice. He went to great trouble to help younger scientists and was a source of advice to all. He was less tolerant of the pompous in high places, and many believed that, perhaps because of that, he received less recognition than he deserved.

Gordon enjoyed golf, and his love of Malaysia never waned. His bluff, cheerful manner often concealed personal discomfort. He suffered from Menière's disease for some years and had had a myocardial infarct, and his final illness prevented him from entering fully into his year as prime warden of the Goldsmiths Company. He married Elsie in 1948, and she and their three children, Elizabeth Ann (Popsie), Alistair, and Sally, survive him. - DAVID J BRADLEY

Charles Edward Gordon Smith, dean of the London School of Hygiene and Tropical Medicine 1971-89, died 4 August aged 67. Born 12 May 1924; educated Forfar Academy, St Andrew's University (MB, ChB 1947). Worked in colonial medical service in Malaysia 1948-57, being virologist at Institute for Medical Research, Kuala Lumpur, 1952-7. Senior lecturer in bacteriology 1957-61 and reader in virology 1961-4, London School of Hygiene and Tropical Medicine; director, Microbiological Research Establishment, Ministry of Defence, 1964-70.

\section{F VAN ZWANENBERG}

MA, DM, DCH, DPH

David van Zwanenberg's death after a long and distressing illness removes an important scholar of the history of medicine.

In 1948 he was appointed medical superintendent of the Isolation Hospital in Ipswich (later renamed St Helen's Hospital), where pulmonary tuberculosis, on which his MD was based, occupied much of his professional attention. He was appointed consultant in infectious diseases and chest medicine in 1963 and proved to be an able administrator and clinician.

He gradually made a reputation for himself as a scholar in the history of medicine. He wrote about

.

